\title{
Analisis Hubungan Laba Akuntansi dan Komponen Arus Kas Dengan Harga Saham
}

Fitri Nuraini*, Andrianto

Universitas Muhammadiyah Surabaya, Indonesia

OPEN ACCESS

ISSN 2548-3501 (online)

Edited by:

Eny Maryanti Reviewed by: Risky A.

${ }^{*}$ Correspondence:

Andrianto

andrianto914@yahoo.com

Received: 15 April 2021

Accepted: 12 June 2021

Published: 31 July 2021

Citation:

Nuraini dan Andrianto (2021)

Analisis Hubungan Laba Akuntansi dan

Komponen Arus Kas Dengan Harga

Saham
This study aims to examine the relationship between accounting profit, operating cash flow, investment cash flow and financing cash flow with stock prices. This study uses data from the financial statements of companies listed in $L Q 45$ on the Indonesian Stock Exchange from 2014- 2019. And the company sampling technique using purposive sampling a number of 34 companies LQ45 in 2014-2019. The research sample was tested using Pearson Correlations analysis and normality test and linearity test. The results of the Pearson Correlations correlation analysis show that the variables of accounting earnings and funding cash flows have a relationship with stock prices with a significance value of $<0.05$. And the operating cash flow and investment cash flow variables have no relationship with stock prices with a significance value of $\geq 0.05$

Keywords: income, operating cash flow, investment cash flow, cash flow financing, stock price

Penelitian ini bertujuan untuk menguji adanya hubungan laba akuntansi, arus kas operasional, arus kas investasi dan arus kas pendanaan dengan harga saham. Penelitian ini menggunakan data laporan keuangan perusahaan yang terdaftar dalam LQ 45 dibursa efek Indonesia mulai tahun 2014-2019. Dan teknik pengambilan sampel perusahaan dengan menggunakan purposive sampling sejumlah 34 perusahaan LQ45 tahun 20142019. Sampel penelitian ini diuji dengan menggunakan analisis korelasi Pearson Correlations dan uji normalitas serta uji linieritas. Hasil analisis korelasi Pearson Correlations menunjukkan bahwa variabel laba akuntansi dan arus kas pendanaan memiliki hubungan dengan harga saham dengan nilai signifikansi $<0,05$. Dan untuk variabel arus kas operasional dan arus kas investasi tidak memiliki hubungan dengan harga saham dengan nilai signifikansi $\geq 0,05$.

Keywords: Laba Akuntansi, Komponen Arus Kas, Harga Saham. 


\section{PENDAHULUAN}

Perkembangan perekonomian di Indonesia sekarang ini menuntut perusahaan bersaing agar tetap survive, hal tersebut menuntut perusahaan untuk melakukan strategi dibidang pemasaran dan inovasi produk. Tetapi selain perusahaan berusaha melakukan strategi untuk bersaing, agar bisa survive tentunya yang paling utama tujuan perusahaan adalah profit oriented. Hampir sebagian besar perusahaan didirikan tujuan utamanya adalah profit oriented. Oleh karena itu kinerja suatu perusahaan dikatakan bagus jika perusahaan memperoleh laba dan dari laba itulah para Investor cenderung akan mulai melirik untuk berinvestasi. Tentunya jika perusahaan secara berkelanjutan mengalami peningkatan laba meskipun sedikit.

Investasi dalam pasar modal dapat berupa investasi saham dan investasi obligasi,tentunya 2 jenis investasi ini berbeda. Jika investasi dalam bentuk saham maka Investor ikut memiliki perusahaan yang sahamnya dibeli,dikarenakan saham merupakan bukti kepemilikan. Tetapi jika investasi dalam bentuk obligasi maka Investor memberikan pinjaman ke perusahaan yang dibeli obligasinya, dikarenakan obligasi merupakan bukti pengakuan hutang. Dan dari 2 jenis investasi dibursa efek yang cenderung beresiko relatif tinggi investasinya adalah saham. Hal ini disebabkan investor dapat memperoleh suatu keuntungan sebagai imbal balik atas investasi tersebut berupa deviden, tetapi sebaliknya investor dapat memperoleh kerugian atas investasi tersebut jika perusahaan mengalami kerugian. Oleh karena itu, investor memerlukan suatu pertimbangan-pertimbangan yang matang untuk berinvestasi, hal ini ditujukan agar nantinya Investor tidak salah melangkah yang menyebabkan justru mengalami kerugian.

Suatu perusahaan dikatakan kinerjanya bagus, selanjutnya berhasil dalam mempertahankan perusahaannya sehingga secara kontinue mengalami keuntungan maka nilai perusahaan itu juga akan bagus. Hal ini dikarenakan nilai perusahaan merupakan kinerja perusahaan yang dicerminkan pada harga saham, dan nilai perusahaan meningkat maka kinerja perusahaan cenderung bagus,sehingga tujuan utama perusahaan yakni profit oriented tercapai. Oleh karena itu bagi para investor, harga saham adalah salah satu faktor yang mempengaruhi investor tersebut untuk melakukan investasi atau tidak. Tentunya harga saham suatu perusahaan selalu mengalami pergerakan naik atau turun tergantung permintaan saham dipasar modal dan kondisi perusahaan. Dan pergerakan harga saham inilah yang sebenarnya tidak terlepas dari adanya informasi akuntansi yakni laporan keuangan. Pada penelitian ini untuk laporan keuangan yang digunakan sebagai acuan dalam hubungannya dengan harga saham adalah laporan laba rugi dan laporan arus kas. Hal tersebut dikarenakan dalam laporan laba rugi mencerminkan kinerja perusahan selama satu periode yang digambarkan pada laba jika kinerja perusahaan bagus, rugi jika kinerja perusahaan tidak bagus.

Selanjutnya untuk laporan arus kas yang merupakan laporan yang menyajikan aliran kas masuk dan keluar selama satu periode yang berasal dari kegiatan operasional, kegiatan investasi, kegiatan pendanaan . Dan dari 3 kegiatan tersebut, masing-masing kegiatan memiliki komponen - komponen arus kas yang membedakannya. Oleh karena itu 2 laporan keungan yaitu laporan laba rugi dan laporan arus kas dengan 3 kegiatan yang masing-masing memiliki komponen- komponen kas yang membedakannya dianggap memiliki hubungan signifikan dengan harga saham. Laporan laba rugi dikaitkan dengan kinerja perusahaan atau nilai perusahaan, jika kinerja perusahaan bagus maka harga saham naik dikarenakan salah satu faktornya bahwa kondisi perusahaan sehat. Dan laporan arus kas dikaitkan dengan komponen-komponen kas dalam 3 kegiatan operasional, investasi dan pendanaan.

Sebelumnya penelitian yang pernah dilakukan terkait arus kas, laba akuntansi dan harga saham adalah (Yuliusman,2009) menunjukkan bahwa arus kas operaisonal memiliki hubungan yang cukup kuat dan signifikan dengan harga saham. Untuk penelitian sebelumnya yang terkait penelitian laba akuntansi dan harga saham serta penelitian total arus kas dan harga saham masih belum ada, sehingga pada penelitian ini peneliti ingin meneliti adanya hubungan laba akuntansi dengan harga saham sesuai dengan teori sinyal (singnalling theory). Dalam teori sinyal (singnalling theory) menjelaskan bahwa kualitas pelaporan keuangan yang mencerminkan nilai perusahaan adalah sinyal positif yang dapat mempengaruhi opini stakeholder, sehingga jika kinerja perusahaan bagus maka sinyal yang diberikan sinyal positif demikian sebaliknya (Akhmadi, 2018). Dan nilai perusahaan dilihat dari pergerakan harga saham dan kualitas laporan keuangan dilihat dari laporan laba rugi dari sisi laba/rugi dan laporan arus kas dari 3 komponen.

Penelitian ini dilakukan pada obyek perusahaan LQ45 yang go publik selama tahun 2014-2019 dengan kriteria tertentu. Hal ini dikarenakan perusahaan LQ45 tersebut selama th 2014-2019 masih dalam posisi going concern serta go public dan tentunya selama jangka waktu tersebut tidak mengalami kerugian, sehingga merupakan alasan peneliti mengambil obyek perusahaan tersebut. Pada penelitian (Yuliusman,2009) menjelaskan adanya hubungan yang kuat arus kas operasi dengan harga saham. Dan penelitian Asrianti dan Rahim (2015) menjelaskan laba kotor dan arus kas investasi berpengaruh positif dan signifikan terhadap harga saham, sedangkan arus kas operasi dan arus kas pendanaan berpengaruh positif dan tidak signifikan terhadap harga saham. Hal ini peneliti ingin menunjukkan bahwa selain adanya pengaruh laba dan arus kas dapat juga adanya hubungan laba dan arus kas dengan harga saham.

Tujuan penelitian dalam penyusunan penelitian ini adalah untuk menganalisa hubungan laba akuntansi, arus kas, dan total arus kas dengan harga saham.

\section{[Figure 1 about here.]}

\section{METODE}

Jenis penelitian ini adalah penelitian kuantitatif menggunakan data sekunder berupa laporan keuangan antara lain laporan posisi keuangan, laporan laba rugi selama tahun 2014-2019 dan harga saham pada saat penutupan (closing price) tahun 20142019. 
Variabel dalam penelitian ini antara lain laba akuntansi (X1), arus kas operasional (X2), arus kas investasi (X3), arus kas pendanaan (X4) dan harga saham (Y). Dan adapun uraian masing-masing variabel independen dan variabel dependen sebagai berikut :

\section{Laba Akuntansi (X1)}

Laba yang digunakan dalam penelitian ini adalah laba bersih setelah pajak tahunan. Laba bersih setelah pajak adalah laba dari penambahan pendapatan dan pengurangan beban non operasional kemudian dikurangi pajak (Dosen, 2021).

\section{Arus Kas Operasional (X2)}

Arus Kas dari aktivitas Operasi sebagai arus masuk dan arus keluar kas atau setara kas selama periode satu tahun yang diperoleh dari kegiatan operasional perusahaan (Weygandt, 2018). Dan pengukuran arus kas operasional :

$$
\mathrm{AKO}=\mathrm{AKO} \text { masuk }-\mathrm{AKO} \text { keluar }
$$

\section{Arus Kas Investasi (X3)}

Arus kas dari aktivitas investasi merupakan cerminan penerimaan dan pengeluaran kas sehubungan dengan sumber daya yang bertujuan menghasilkan pendapatan dan arus kas masa depan (Weygandt, 2018). Dan pengukuran arus kas investasi:

$$
\mathrm{AKI}=\mathrm{AKI} \text { masuk }- \text { AKI keluar }
$$

\section{Arus Kas Pendanaan (X4)}

Arus kas dari aktivitas pendanaan yang merupakan arus kas masuk dan keluar dan setara kas dari aktivitas/kegiatan yang mengakibatkan perubahan dalam jumlah serta komposisi modal dan pinjaman perusahaan (Weygandt, 2018). Dan pengukuran arus kas pendanaan :

$\mathrm{AKP}=\mathrm{AKP}$ masuk $-\mathrm{AKP}$ keluar

\section{Harga Saham (Y)}

Haega saham merupakan bukti/tanda kepemilikan dalam suatu perusahaan sebagai reflesi dari suatu keputusan investasi, pendanaan dan pengelolaan aset (Abi, n.d.). Harga saham yang digunakan dalam penelitian ini adalag harga saham pada saat penutupan (closing price) (Asrianti \& Rahim, 2015).

\section{Populasi dan Sampel}

Populasi dalam penelitian ini adalah perusahaan yang terdaftar diBursa Efek Indonesia dan terdaftar pada indeks LQ45 berjumlah 45 perusahaan pada periode 2014-2019. Adapun alasan memilih perusahaan yang terdaftar pada indeks LQ 45 dikarenakan perusahaan yang sahamnya terdaftar pada indeks LQ 45 memiliki likuiditas saham tertinggi dibandingkan dengan saham perusahaan lain yang terdaftar di Bursa Efek Indonesia. Dan dari total populasi sebesar 45 perusahaan yang terdaftar pada indeks LQ 45, perusahaan yang diambil menjadi objek penelitian adalah 34 perusahaan dengan metode pengambilan sampel menggunakan purposive sampling.

\section{Metode dan Teknik Analisis}

Analisis korelasi Pearson Correlations bertujuan untuk menguji hipotesis adanya hubungan antara variabel dengan jenis data skala dan rasio. Analisis ini digunakan untuk menganalisis hubungan antara variabel independen antara lain laba akuntansi (X1), arus kas operasional (X2), arus kas investasi (X3) dan arus kas pendanaan (X4) dengan variabel dependen yaitu harga saham (Y). Untuk mengetahui signifikan atau tidaknya korelasi (hubungan) antara variabel independen dengan variabel dependen dengan prosedur tingkat signifikan $(\alpha)=5 \%$ dengan kriteria pengujian sebagai berikut (Djuniadi, Affifudin Muhammad, 2017) :

Jika tingkat signifikan (p-value) $\geq 0,05$ maka tidak terdapat hubungan laba akuntansi (X1), arus kas operasional (X2), arus kas investasi (X3) dan arus kas pendanaan (X4) dengan variabel dependen yaitu harga saham (Y).

Jika tingkat signifikan ( $p$-value) $<0,05$ maka terdapat hubungan laba akuntansi (X1), arus kas operasional (X2), arus kas investasi (X3) dan arus kas pendanaan (X4) dengan variabel dependen yaitu harga saham (Y).

\section{Uji Normalitas}

Uji normalitas bertujuan untuk menguji apakah dalam model regresi variabel dependen dan independen keduanya mempunyai distribusi normal atau tidak. Uji normalitas ini menggunakan Normalitas P-Plot of regression standardized residual terhadap pengujian pada keseluruhan variabel dalam penelitian ini. Uji normalitas data dilihat dengan melihat pola pada kurva penyebaran pada grafik P-Plot. Jika pola penyebaran memiliki garis normal kurva maka dapat dikatakan data distribusi normal (Ghozali, 2013).

\section{Uji Linearitas}

Uji Linieritas bertujuan untuk menguji apakah dalam model regresi variabel dependen dan independen keduanya mempunyai hubungan linier atau tidak. Hubungan dikatakan linier jika kenaikan skor variabel bebas diikuti oleh kenaikan skor variabel terikat. Untuk itu harus diuji dengan uji F. Dan dengan kriteria pengambilan keputusan, taraf signifikansi $(\alpha)$ adalah 5\%. Jika F hitung $>\mathrm{F}$ tabel maka hubungan antar variabel bebas dan variabel terikat tidak linier (Ghozali, 2013).

\section{Hasil Dan Pembahasan}

Analisis statistik dilakukan dengan menggunakan korelasi sederhana Pearson Correlations dan uji normalitas, uji linieritas.

\section{Uji Normalitas}

\section{[Figure 2 about here.]}

Berdasarkan gambar diatas uji normalitas dengan menggunakan analisis grafik normal P-P Plot of Regression Standardized Residual. Hasil pengujian dengan menggunakan analisis grafik normal normal $P-P$ menunjukkan bahwa model regresi terdistribusi normal, karena titik-titik menyebar di sekitar diagonal serta penyebarannya mengikuti arah diagonal. 
Selanjutnya berdasarkan gambar 3 uji normalitas dengan menggunakan analisis grafik normal graph histogram. Dan hasil pengujian dengan menggunakan analisis grafik normal graph histogram menunjukkan bahwa data variabel independen dan dependen membentuk lengkung seperti lonceng, Hal tersebut berarti asumsi normalitas semua variabel terpenuhi. Kriteria pengujian yakni jika lengkung membentuk seperti lonceng maka kecenderungan data berdistribusi normal. Jika lengkung tidak membentuk seperti lonceng maka kecenderungan data berdistirbusi tidak normal.

\section{Uji Linieritas}

Uji Linieritas bertujuan untuk menguji apakah dalam model regresi variabel dependen dan independen keduanya mempunyai hubungan linier atau tidak. Hubungan dikatakan linier jika kenaikan skor variabel bebas diikuti oleh kenaikan skor variabel terikat.

\section{[Table 1 about here.]}

Berdasarkan tabel 1 diatas menunjukkan $\mathrm{f}$ hitung senilai 2,467 dan $\mathrm{f}$ tabel yang dihitung dengan rumus df $(1)=\mathrm{k}-1, \mathrm{df}(2)=\mathrm{n}$ $\mathrm{k}-1$. Dan dengan jumlah sampel 204 dan variabel independen serta variabel dependen sebanyak 5 maka $\mathrm{df}(1)=4$ dan $\mathrm{df}(2)=$ 198 dan $\mathrm{f}$ tabel senilai 2,420. Hasil $\mathrm{f}$ hitung sebesar 2,467 dan $\mathrm{f}$ tabel sebesar 2,420 maka kriteria pengambilan keputusan dengan taraf signifikansi $(\alpha)$ adalah $5 \%$. , F hitung $>\mathrm{F}$ tabel $(2,467>2,420)$ sehingga disimpulkan hubungan antar variabel bebas dan variabel terikat tidak linier (Ghozali, 2013).

\section{Analisis Data}

Analisis Korelasi Parsial Laba Akuntansi dan Arus Kas dengan Harga Saham Perusahaan LQ 45 di Bursa Efek Indonesia tahun 2014-2019

Berikut ini merupakan hasil analisis korelasi secara parsial untuk melihat hubungan masing-masing variabel antara lain variabel laba akuntansi, arus kas operasional, arus kas investasi, dan arus kas pendanaan dengan harga saham perusahaan LQ45 di Bursa Efek Indonesia tahun 2014-2019.

[Table 2 about here.]

\begin{abstract}
Analisis Hubungan Laba Akuntansi dengan Harga Saham Perusahaan LQ 45 di Bursa Efek Indonesia tahun 20142019
\end{abstract}

\section{[Table 3 about here.]}

Berdasarkan tabel 3 laba akuntansi menghasilkan nilai signifikansi senilai 0,019 dan tingkat signifikansi 0,05 (0,019 $<0,05)$ maka hasil pengujian tersebut menunjukkan terdapat hubungan laba akuntansi dengan harga saham perusahaan LQ45 diBursa Efek Indonesia tahun 2014-2019.
Analisis Hubungan Arus Kas Operasional dengan Harga Saham Perusahaan LQ 45 di Bursa Efek Indonesia tahun 2014-2019

\section{[Table 4 about here.]}

Berdasarkan tabel 4 arus kas operasional menghasilkan nilai signifikansi senilai 0,210 dan tingkat signifikansi $0,05(0,210>$ $0,05)$ maka hasil pengujian tersebut menunjukkan terdapat tidak terdapat hubungan arus kas operasional dengan harga saham perusahaan LQ45 diBursa Efek Indonesia tahun 2014-2019.

Analisis Hubungan Arus Kas Investasi dengan Harga Saham Perusahaan LQ 45 di Bursa Efek Indonesia tahun 2014-2019

$$
\text { [Table } 5 \text { about here.] }
$$

Berdasarkan tabel 5 arus kas investasi menghasilkan nilai signifikansi senilai 0,855 dan tingkat signifikansi $0,05(0,855>$ $0,05)$ maka hasil pengujian tersebut menunjukkan terdapat tidak terdapat hubungan arus kas investasi dengan harga saham perusahaan LQ45 diBursa Efek Indonesia tahun 2014-2019.

Analisis Hubungan Arus Kas Pendanaan dengan Harga Saham Perusahaan LQ 45 di Bursa Efek Indonesia tahun 2014-2019

\section{[Table 6 about here.]}

Berdasarkan tabel 6 arus kas pendanaan menghasilkan nilai signifikansi senilai 0,018 dan tingkat signifikansi $0,05(0,018<$ $0,05)$ maka hasil pengujian tersebut menunjukkan terdapat terdapat hubungan arus kas pendanaan dengan harga saham perusahaan LQ45 diBursa Efek Indonesia tahun 2014-2019.

Analisis Korelasi Simultan Laba Akuntansi dan Arus Kas dengan Harga Saham Perusahaan LQ 45 di Bursa Efek Indonesia tahun 2014-2019

\section{[Table 7 about here.]}

Berdasarkan tabel 7 menunjukkan hubungan secara simultan antara laba akuntansi, arus kas operasional, arus kas investasi dan arus kas pendanaan dengan harga saham perusahaan LQ45 diBursa Efek Indonesia tahun 2014-2019 dengan menggunakan nilai $\mathrm{f}$ hitung dan $\mathrm{f}$ tabel. Nilai $\mathrm{f}$ hitung yang dihasilkan adalah sebesar 2,467. Untuk itu nilai signifikansi yang ditunjukkan pada tabel 3.5 senilai 0,046, menunjukkan angka yang lebih kecil dari level signifikansi 0,05 . Hal ini berarti secara simultan terdapat hubungan yang signifikansi antara laba akuntansi, arus 
kas operasional, arus kas investasi dan arus kas pendanaan dengan harga saham.

Laporan keuangan merupakan laporan yang menunjukkan informasi akuntansi mengenai kinerja perusahaan dan posisi keuangan selama periode tertentu bagi stakeholder sebagai dasar pengambilan keputusan. Laporan keuangan sendiri secara umum terdiri dari laporan laba rugi, laporan perubahan ekuitas, laporan posisi keuangan, laporan arus kas dan catatan atas laporan keuangan. Dan dari definisi laporan keuangan tersebut telah menunjukkan bahwa informasi akuntansi dalam laporan keuangan sangatlah penting dan berarti bagi stakeholder, meskipun masingmasing stakeholder memiliki kepentingan dalam penggunaan laporan keuangan.

\section{Uji R2 (Koefisien Determinasi)}

\section{[Table 8 about here.]}

Berdasarkan tabel 8 menunjukkan bahwa besarnya adjusted $R 2$ adalah sebesar 0,028 . Hal tersebut berarti bahwa besarnya kontribusi variabel $\mathrm{x}$ antara lain laba akuntansi, arus kas operasi, arus kas investasi dan arus kas pendanaan terhadap harga saham adalah senilai 2,8\%. Dan sisanya sebesar 97,2\% ditentukan oleh variabel-variabel lainnya yang tidak dimasukkan dalam penelitian ini.

\section{Analisis Hubungan Laba Akuntansi dan Arus Kas dengan Harga Saham Perusahaan LQ 45 di Bursa Efek Indonesia tahun 2014-2019}

Berdasarkan hasil korelasi secara parsial menunjukkan nilai signifikansi korelasi masing-masing variabel $\mathrm{x}$ antara lain laba akuntansi senilai 0,019, arus kas operasional sebesar 0,210 , arus kas investasi sebesar 0,855 dan arus kas pendanaan senilai 0,018. Dan dari hasil korelasi masing-masing nilai signifikansi korelasi yang memiliki hubungan dengan harga saham adalah laba akuntansi dan arus kas pendanaan. Oleh karena itu dengan hasil korelasi tersebut menunjukkan bahwa secara definisi laporan laba rugi yakni laporan yang menyajikan informasi akuntansi mengenai kinerja keuangan telah terbukti. Jika kinerja perusahaan bagus maka penilaian perusahaan mengalami kenaikan sehingga harga saham juga mengalami kenaikan. Tetapi sebaliknya jika kinerja perusahaan tidak bagus maka penilaian perusahaan mengalami penurunan sehingga harga saham juga mengalami penurunan. Hal tersebut sesuai dengan teori sinyal (singnalling theory) menjelaskan bahwa pengungkapan laporan tahunan perusahaan merupakan informasi yang penting bagi stakeholder yakni investor dalam pengambilan keputusan (Akhmadi, 2018). Dalam hal ini dilihat dari kualitas pelaporan keuangan yang mencerminkan nilai perusahaan adalah sinyal positif yang dapat mempengaruhi opini stakeholder, sehingga jika kinerja perusahaan bagus maka sinyal yang diberikan sinyal positif demikian sebaliknya.

Selanjutnya untuk laporan keuangan lainnya yang memiliki hubungan dengan harga saham yakni laporan arus kas. Laporan arus kas adalah laporan yang menyajikan informasi akuntansi mengenai aliran kas masuk dan kas keluar dari 3 komponen, antara lain arus kas operasional, arus kas investasi dan arus kas pendanaan (Setyawan, 2020). Masingmasing komponen memiliki aktivitas masing- masing, arus kas operasional merupakan aliran kas masuk dan keluar dari aktivitas kegiatan operasional perusahaan yang ditunjukkan perubahan aset lancar, kewajiban lancar, pendapatan dan beban operasional. Arus kas investasi merupakan aliran kas masuk dan keluar dari aktivitas kegiatan penjualan dan pembelian aset tidak lancar. Dan arus kas pendanaan merupakan aliran kas masuk dan keluar dari aktivitas pembiayaan yang ditunjukkan perubahan kewajiban jangka panjang dan ekuitas (Weygandt, 2018).

Dan dari 3 komponen laporan arus kas yang memiliki aktivitas masing-masing yang cenderung memiliki hubungan dengan harga saham adalah arus kas pendanaan. Hal ini disebabkan dalam aktivitas arus kas pendanaan melibatkan adanya perubahan dari ekuitas, ekuitas disini adalah ekuitas pemegang saham. Ekuitas pemegang saham dibedakan pada jenis saham yakni ekuitas pemegang saham biasa dan saham istimewa. Sesuai dengan teori sinyal (singnalling theory) menjelaskan bahwa pengungkapan laporan tahunan perusahaan merupakan informasi yang penting bagi stakeholder yakni investor dalam pengambilan keputusan (Akhmadi, 2018). Dalam hal ini dilihat dari kualitas pelaporan keuangan yang mencerminkan nilai perusahaan adalah sinyal positif yang dapat mempengaruhi opini stakeholder, sehingga jika sinyal positif maka kecenderungan investor dalam pengambilan keputusan investasi juga akan bernilai positif juga. Bernilai positif berarti investor akan melakukan penambahan saham, tetapi jika sebaliknya sinyal negatif menimbulkan investor dalam pengambilan keputusan cenderung bernilai negatif atau dapat melakukan penjualan saham (Nursita, 2021). Hal tersebut dikarenakan pemikiran investor jika perusahaan sudah mengalami sinyal negatif maka suatu saat periode berikutnya akan cenderung mengalami hal yang sama. Penelitian ini bertentangan dengan penelitian (Yuliusman, 2009) menjelaskan bahwa arus kas operasional yang memiliki hubungan dengan harga saham dengan nilai signifikansi senilai 0,042 . Dan secara parsial menunjukkan bahwa arus kas operasi dan arus kas investasi tidak memiliki hubungan dengan harga saham. Hal ini berarti komponen arus kas operasi dan arus kas investasi belum mencerminkan nilai perusahaan yang dapat mempengaruhi opini stakeholder yakni investor dalam pengambilan keputusan.

\section{KESIMPULAN}

Penelitian ini dilakukan untuk mengetahui hubungan laba akuntansi, arus kas operasional, arus kas investasi dan arus kas pendanaan dengan harga saham. Berdasarkan data yang telah dikumpulkan dan diuji, maka dapat disimpulkan antara lain : laba akuntansi dan arus kas pendanaan memiliki hubungan dengan harga saham dengan nilai signifikansi korelasi $<0,05$. Dan selanjutnya untuk variabel arus kas operasional dan arus kas investasi tidak memiliki hubungan dengan harga saham. Dua variabel yaitu laba akuntansi dan arus kas pendanaan 
membuktikan bahwa teori sinyal (Signalling theory) itu memang benar bahwa pengungkapan laporan tahunan perusahaan merupakan informasi yang penting bagi stakeholder yakni investor dalam pengambilan keputusan. Dalam hal ini dilihat dari kualitas pelaporan keuangan yang mencerminkan nilai perusahaan adalah sinyal positif yang dapat mempengaruhi opini stakeholder, sehingga jika sinyal positif maka kecenderungan investor dalam pengambilan keputusan investasi juga akan bernilai positif juga. Untuk itu dari lima jenis laporan keuangan dua diantaranya memiliki hubungan dengan harga saham, yaitu laporan laba rugi dan laporan arus kas.

\section{REFERENCES}

Abi, A. (N.D.). Pengertian Saham, Jenis Dan Harga Saham. Jam 10.17 Pm.

Akhmadi, P. R. A. (2018). Profitabilitas, Rasio Solvabilitas Dan Harga Saham; Studi Empirik Pada Perusahaan Subsektor Batubara Yang Terdaftar Di Bursa Efek Indonesia Periode 2010-2014. Jurnal Riset Akuntansi Terpadu, 11(1), 61-71.

Asrianti, \& Rahim, S. (2015). Pengaruh Laba Dan Arus Kas Terhadap Harga Saham Perusahaan Lq 45 Di Bursa Efek Indonesia. Akuntansi Aktual, 3(1), 17. Http://Journal2.Um.Ac.Id/Index.Php/Jaa/Article/View $/ 7181$

Djuniadi, Affifudin Muhammad, L. W. (2017). Statistik Inferensial - Teori, Aplikasi Dan Latihan Soal. Program Pascasarjana Universitas Negeri Semarang.

Dosen, P. (2021). Laba. Tanggal 23 Pebruari 2021. Https:/Www.Dosenpendidikan.Co.Id/Laba-Adalah/

Ghozali, I. (2013). Aplikasi Analisis Multivariate Dengan Program IBM SPSS 21 Update PLS Regresi (7th Ed.). Badan Penerbit Universitas Diponegoro.

Nursita, M. (2021). Pengaruh Laba Akuntansi, Arus Kas Operasi, Arus Kas Investasi, Arus Kas Pendanaan, Dan Ukuran Perusahaan Terhadap Return Saham. Going Concern : Jurnal Riset Akuntansi, 16(1), 1-15. https://doi.org/10.32400/gc.16.1.32435.2021

Setyawan, B. (2020). Pengaruh Arus Kas Koperasi, Arus Kas Investasi, Arus Kas Pendanaan Dan Laba Akuntansi Terhasap Return Saham Pasa Emiten Sub Sektor Makanan Dan Minuman. Equilibrium : Jurnal Ilmiah Ekonomi, Manajemen Dan Akuntansi, 9(1), 48-58. https://doi.org/10.35906/je001.v9i1.486

Weygandt, K. K. (2018). Pengantar Akuntansi 2 Berbasis IFRS (2nd ed.). Penerbit Salemba Empat.

Uliusman. (2009). Analisis Hubungan Arus Kas Dengan Harga Saham Pada Perusahaan Yang Tergabung Dalam Kelompok Lq 45 Di Bursa Efek Indonesia Periode 2007 - 2008 Yuliusman. Jurnal Infestasi, 5(2), 85-95.

https://journal.trunojoyo.ac.id/infestasi/article/view/

https://www.idnfinancials.com/

https://www.indopremier.com/
Copyright () 2020 and. This is an open-access article distributed under the terms of the Creative Commons Attribution License (CC $B Y)$. The use, distribution or repro- duction in other forums is permitted, provided the original author(s) and the copy-right owner(s) are credited and that the original publication in this journal is cited, in accordance with accepted academic practice. No use, distribution or reproduction is permitted which does not comply with these terms. 


\section{LIST OF TABLE}

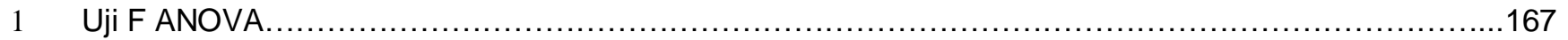

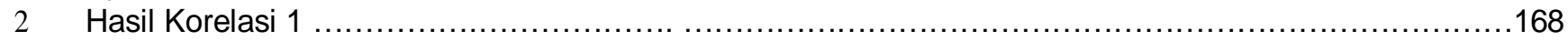

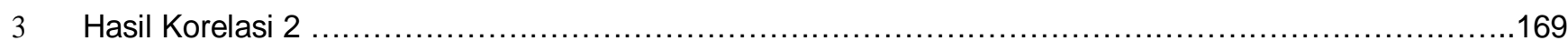

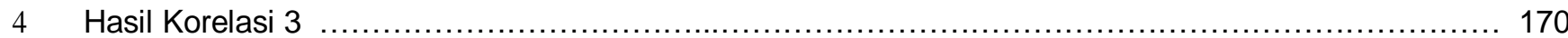

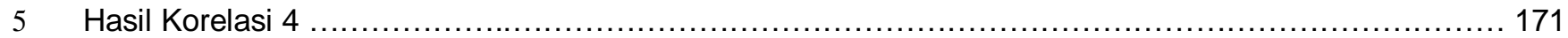

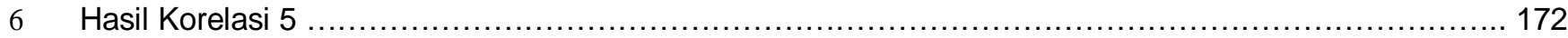

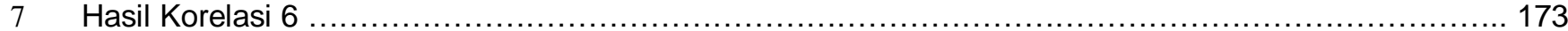

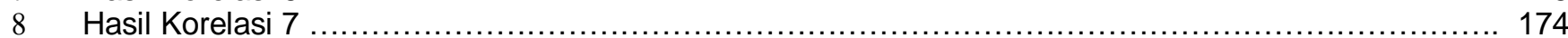

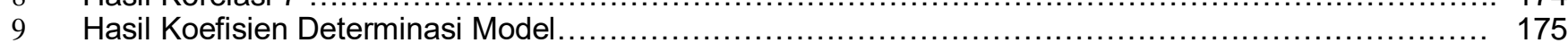


Tabel 1 / Tabel 1 Hasil Uji F ANOVA ${ }^{\mathrm{a}}$

\begin{tabular}{|c|c|c|c|c|c|c|}
\hline & Model & Sum of Squares & $\mathrm{df}$ & $\begin{array}{c}\text { Mean } \\
\text { Square }\end{array}$ & $\mathrm{F}$ & Sig. \\
\hline \multirow[t]{3}{*}{1} & Regression & 2313597326.237 & 4 & $\begin{array}{c}57839933 \\
1.559 \\
\end{array}$ & 2.467 & $.046^{\mathrm{b}}$ \\
\hline & Residual & 46654922271.425 & 199 & $\begin{array}{c}23444684 \\
5.585 \\
\end{array}$ & & \\
\hline & $\begin{array}{rr}\text { Total } & 489 \\
& 597\end{array}$ & $\begin{array}{ll}8519 & 203 \\
662 & \\
6\end{array}$ & & & & \\
\hline
\end{tabular}


Tabel 2 / Hasil Korelasi 1 Correlations

\section{Correlations}

\begin{tabular}{|c|c|c|c|c|c|c|}
\hline & & Laba_akuntansi & $\mathrm{AKO}$ & AKI & AKP & Harga_Saham \\
\hline \multirow[t]{3}{*}{ Laba_akuntansi } & $\begin{array}{l}\text { Pearson } \\
\text { Correlation }\end{array}$ & 1 & $.717^{* * *}$ & $-.506^{* *}$ & $-.341^{* *}$ & $.163^{*}$ \\
\hline & Sig. (2-tailed) & & .000 & .000 & .000 & .019 \\
\hline & $\mathrm{N}$ & 204 & 204 & 204 & 204 & 204 \\
\hline \multirow[t]{3}{*}{ AKO } & $\begin{array}{l}\text { Pearson } \\
\text { Correlation }\end{array}$ & $.717^{* *}$ & 1 & $-.656^{* *}$ & $-.446^{* *}$ & .088 \\
\hline & Sig. (2-tailed) & .000 & & .000 & .000 & .210 \\
\hline & $\mathrm{N}$ & 204 & 204 & 204 & 204 & 204 \\
\hline \multirow[t]{3}{*}{ AKI } & $\begin{array}{l}\text { Pearson } \\
\text { Correlation }\end{array}$ & $-.506^{* *}$ & $-.656^{* *}$ & 1 & .023 & -.013 \\
\hline & Sig. (2-tailed) & .000 & .000 & & .742 & .855 \\
\hline & $\mathrm{N}$ & 204 & 204 & 204 & 204 & 204 \\
\hline \multirow[t]{3}{*}{ AKP } & $\begin{array}{l}\text { Pearson } \\
\text { Correlation }\end{array}$ & $-.341^{* * *}$ & $-.446^{* * *}$ & .023 & 1 & $-.166^{*}$ \\
\hline & Sig. (2-tailed) & .000 & .000 & .742 & & .018 \\
\hline & $\mathrm{N}$ & 204 & 204 & 204 & 204 & 204 \\
\hline \multirow[t]{3}{*}{ Harga_Saham } & $\begin{array}{l}\text { Pearson } \\
\text { Correlation }\end{array}$ & $.163^{*}$ & .088 & -.013 & $-.166^{*}$ & 1 \\
\hline & Sig. (2-tailed) & .019 & .210 & .855 & .018 & \\
\hline & $\mathrm{N}$ & 204 & 204 & 204 & 204 & 204 \\
\hline **. Correlation i & $\mathrm{s}$ significant at $\mathrm{tl}$ & .01 level (2-tailec & & & & \\
\hline
\end{tabular}


Tabel 3 / Hasil Korelasi 2

\section{Correlations}

\begin{tabular}{llcc}
\hline & & Laba_akuntansi & Harga_Saham \\
\hline Laba_akuntansi & $\begin{array}{l}\text { Pearson } \\
\text { Correlation }\end{array}$ & 1 & $.163^{*}$ \\
\cline { 2 - 4 } & Sig. (2-tailed) & & .019 \\
\cline { 2 - 4 } & $\mathrm{N}$ & 204 & 204 \\
\hline Harga_Saham & $\begin{array}{l}\text { Pearson } \\
\text { Correlation }\end{array}$ & $.163^{*}$ & 1 \\
\cline { 2 - 4 } & Sig. (2-tailed) & .019 & \\
\cline { 2 - 4 } & $\mathrm{N}$ & 204 & 204 \\
\hline
\end{tabular}

*. Correlation is significant at the 0.05 level (2-tailed). 
Tabel 4 / Hasil Korelasi 3 Correlations

\section{Correlations}

\begin{tabular}{llcc}
\hline & & AKO & Harga_Saham \\
\hline AKO & Pearson Correlatio & 1 & .088 \\
\cline { 2 - 4 } & Sig. (2-tailed) & & .210 \\
\cline { 2 - 4 } & $\mathrm{N}$ & 204 & 204 \\
\hline Harga_Saham & Pearson & .088 & 1 \\
& Correlation & & \\
\cline { 2 - 4 } & Sig. (2-tailed) & .210 & \\
\cline { 2 - 4 } & $\mathrm{N}$ & 204 & 204 \\
\hline
\end{tabular}


Tabel 5 / Hasil Korelasi 4 Correlations

\section{Correlations}

\begin{tabular}{llcc}
\hline & & AKI & Harga_Saham \\
\hline AKI & $\begin{array}{l}\text { Pearson } \\
\text { Correlation }\end{array}$ & 1 & -.013 \\
\cline { 2 - 3 } & Sig. (2-tailed) & & .855 \\
\cline { 2 - 3 } & $\mathrm{N}$ & 204 & 204 \\
\hline Harga_Saham & $\begin{array}{l}\text { Pearson } \\
\text { Correlation }\end{array}$ & -.013 & 1 \\
\cline { 2 - 4 } & Sig. (2-tailed) & .855 & \\
\cline { 2 - 4 } & $\mathrm{N}$ & 204 & 204 \\
\hline
\end{tabular}


Tabel 6 / Hasil Korelasi 5 Correlations

\section{Correlations}

\begin{tabular}{llcc}
\hline & & AKP & Harga_Saham \\
\hline AKP & $\begin{array}{l}\text { Pearson } \\
\text { Correlation }\end{array}$ & 1 & $-.166^{*}$ \\
\cline { 2 - 3 } & Sig. (2-tailed) & & .018 \\
\cline { 2 - 3 } & $\mathrm{N}$ & 204 & 204 \\
\hline Harga_Saham & $\begin{array}{l}\text { Pearson } \\
\text { Correlation }\end{array}$ & $-.166^{*}$ & 1 \\
\cline { 2 - 3 } & Sig. (2-tailed) & .018 & \\
\cline { 2 - 3 } & $\mathrm{N}$ & 204 \\
\hline
\end{tabular}


Tabel 7 / Hasil Korelasi Secara Simultan

\begin{tabular}{|c|c|c|c|c|c|c|}
\hline \multicolumn{7}{|c|}{ ANOVA $^{\mathrm{a}}$} \\
\hline \multirow{4}{*}{$\frac{M c}{1}$} & & Sum of Squares & df & Mean Square & $\mathrm{F}$ & Sig. \\
\hline & Regression & 2313597326.237 & 4 & 578399331.559 & $\begin{array}{c}2.46 \\
7\end{array}$ & $.046^{\mathrm{b}}$ \\
\hline & Residual & 46654922271.425 & 199 & 234446845.585 & & \\
\hline & Total & 48968519597.662 & 203 & & & \\
\hline \multicolumn{7}{|c|}{ a. Dependent Variable: Harga_Saham } \\
\hline \multicolumn{7}{|c|}{ b. Predictors: (Constant), Total_Kas, AKP, AKI, Laba_akuntansi } \\
\hline
\end{tabular}


Tabel 8 / Hasil Koefisien Determinasi Model Summary ${ }^{\mathrm{b}}$

\begin{tabular}{ccccc}
\hline Mode 1 & \multirow{2}{*}{ R Square } & Adjusted & Std. Error of the Estimate \\
& & & RSquare & \\
\hline 1 & $.217^{\mathrm{a}}$ & .047 & .028 & $\begin{array}{c}15311.6571 \\
8\end{array}$ \\
\hline
\end{tabular}




\section{LIST OF FIGURES}

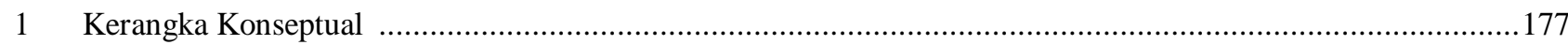

2 Hasil Uji Normal P-P Plot of RegressionnStandardized Residual ....................................................................... 178 
Figure 1/ Kerangka Konseptual

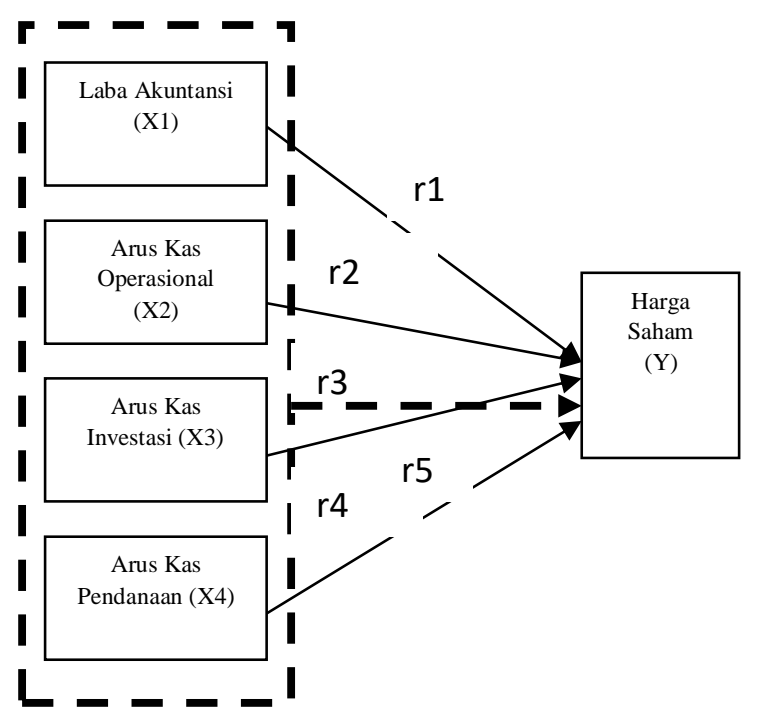


Figure 2/ Hasil Uji Normal P-P Plot of Regression Standardized Residual

Normal P-P Plot of Regression Standardized Residual

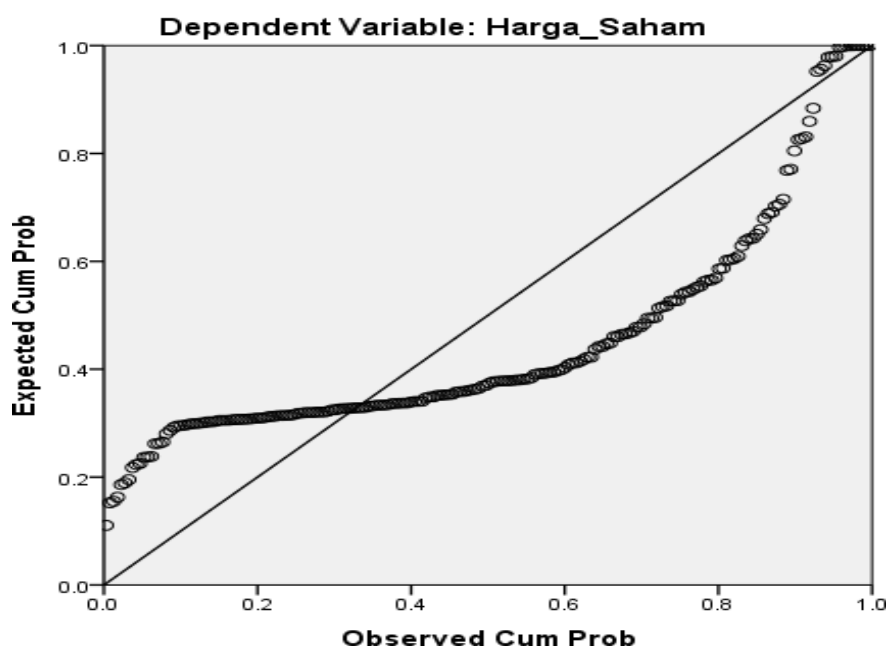


Figure 3/ Hasil Uji Normal graphhistogram

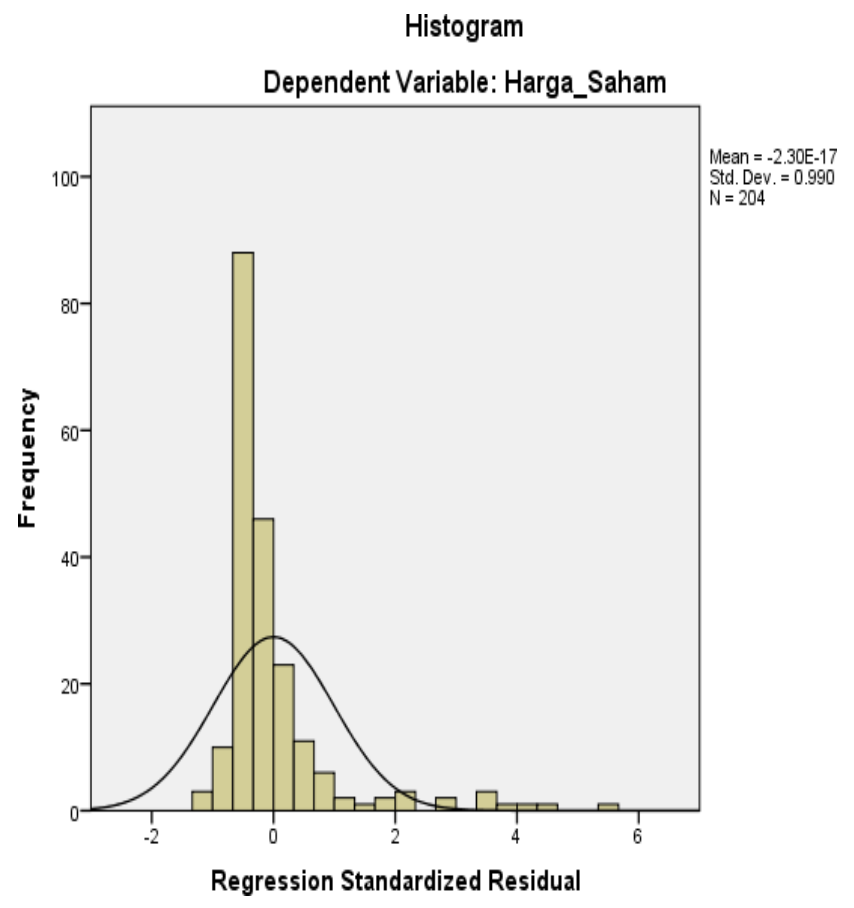

